International Journal of Instruction

e-ISSN: 1308-1470 • www.e-iji.net

Article submission code:

20191101105638

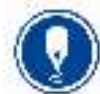

January $2021 \bullet$ Vol.14, No.1

p-ISSN: 1694-609X

pp. $947-962$

Received: 01/11/2019

Revision: 11/08/2020
Accepted: 03/09/2020

OnlineFirst:12/12/2020

\title{
Empowering Scientific Thinking Skills of Students with Different Scientific Activity Types through Guided Inquiry
}

\section{Seto Prio Asmoro}

Post-Graduates Programme of Science Education, Sebelas Maret University, Indonesia, setowannabe@gmail.com

\section{Suciati}

Prof., corresponding author, Post-Graduates Programme of Science Education, Sebelas Maret University, Indonesia, suciati.sudarisman@yahoo.com

\section{Baskoro Adi Prayitno}

Dr., Post-Graduates Programme of Science Education, Sebelas Maret University, Indonesia, baskoro_ap@fkip.uns.ac.id

Students' scientific thinking skills can be empowered by implementing certain learning models in which they are given opportunities to perform some scientific activities. This study aims at investigating: (1) effect of guided inquiry learning model on scientific thinking skills; (2) effect of different types of scientific activities on scientific thinking skills; and (3) interaction between learning model and type of scientific activities on scientific thinking skills. Design of this research is using Pre-Post test non equivalent group. The tests were based on Kuhn's scientific thinking skill indicators. There were 263 eleventh-grade science students in Pacitan, Indonesia, chosen as participants. Purposive sampling technique was used to determine its samples. The data were analysed by using ANCOVA ( $\mathrm{p}=$ $0.05 \%)$ and LSD. The results of the study show that: (1) The guided inquiry had a highest potential to improve the students' scientific thinking skills; (2) The students with 'Type a' had a highest scientific thinking skill; (3) when the guided inquiry was implemented to the students with 'Type a', it gave a significant improvement to their scientific thinking skills. Based on this result, we should concern that the successful implementation of the guided inquiry is closely related to the students' scientific activity type.

Keywords: scientific thinking skills, expository learning, guided inquiry, structured inquiry, type of scientific activity

\section{INTRODUCTION}

The 21st Century learning framework (Partnership for 21st Century Learning) requires students to have skills, knowledge, and abilities in the fields of technology, media, and information (Saveedra \& Opfer, 2012). However, they also need to control and select

Citation: Asmoro, S. P., Suciati. \& Prayitno, B. A. (2021). Empowering Scientific Thinking Skills of Students with Different Scientific Activity Types through Guided Inquiry. International Journal of Instruction, 14(1), 947-962. https://doi.org/10.29333/iji.2021.14156a 
every use of information technology wisely so as to utilise technology to compensate for the fast changing times optimally. In order to optimise students' skills in selecting information and communication technology in society, one of the efforts is by practicing students' scientific thinking abilities (Thitima and Sumalee, 2012). Therefore, empowering students' scientific thinking abilities is very important in the present time learning.

Scientific thinking skill much deals with the way to observe, record, describe, question, explain, and draw a conclusion (Lackaff, 2013). This is in line with the statement of Kuhn (2010), who stated that scientific thinking is a process of searching for knowledge that includes what is shown up in mind with purpose. Its purpose is to enhance knowledge. Hendrich et al. (2018) added that students define scientific thinking like what happens in a laboratory, not as something that has value to solve the problem in daily life.

Scientific thinking skill has some stages of thinking. It includes inquiry, analysis, inference, and argument. The inquiry phase is an important part in which the objective of activity is made. The inquiry phase comprises the process of determining the objectives of the activities, identifying the data and initial phenomenon, connecting the findings from the phenomenon to the initial knowledge which the students have already had, and formulating the problem. The analysis phase is a productive analysis which includes the operation of taking, processing, interpreting, and displaying the obtained data from the previous stages. The inference stage is the conclusion stage in which the products result from the previous activities. This stage includes the process of compiling the data and empirical evidence into a theory, searching for other factors that can influence the result, coordinating fact and theory, and drawing conclusion. The argument stage is the final stage in which there is expectedly a process of expressing opinion of the fact and theory, presenting the different result that is found, making a rebuttal to the theory that has been submitted, and maintaining consistency of the given statement (Kuhn, 2010).

In addition, the scientific thinking abilities can also have a positive impact on students' learning outcomes (Ratnasari, et al., 2019). It is in accordance with the opinion of Prayitno and Suciati (2018) who stated that scientific thinking is a process that involves students' cognitive skill in constructing knowledge. Kagee's research (2010) also supports the importance of scientific thinking for students. By having high scientific thinking abilities, students are able to criticise and make knowledge claims and arguments about behaviour change from a scientific perspective.

In real condition, based on the scientific thinking ability test, most of the students of 8 State Senior Secondary Schools (hereinafter called SMAN) in Pacitan regency still have low scientific thinking abilities. There are $6.47 \%$ students at the concrete level and $55.72 \%$ of the students are at the low formal level. In addition, there are $37.81 \%$ of the students at upper level and none of them are at post formal level. The data indicate that most of the students $(55.72 \%)$ are at low formal level, meaning that most SMAN students in Pacitan are only able to think about concrete experiences, and they are not 
able to think more abstract, idealistic and logical ways (Asmoro S.P., Suciati, Prayitno, B.A., 2018).

Hoover (2010) mentions one effort to empower scientific thinking abilities by changing the way of learning. The way of learning should be based on scientific approaches. Learning based on scientific approaches encourages students to be directly involved in the learning process. They do some activities such as observing, asking, reasoning, associating, and communicating so that they can get direct learning experience when learning material (Gerde, 2010). However, in the scientific-based learning process at Senior Secondary School, teachers must also act as facilitators to guide their students so that they do not mislead in understanding the concept of the presented material. Scientific-based learning which still involves teachers to guide and direct students in scientific activities is guided inquiry learning.

Guided inquiry uses scientific activities in real context through experiments to create a new understanding. Thus, the students are actively involved in the process of scientific thinking. Learning, seen from constructivism, not only provides theory but also provides real experience for the students (Coffman, 2017). This guided inquiry invites students to make an invention in which they can combine some concepts from observing, classifying, guessing, explaining, measuring, and making conclusion with guidance or direction from teachers. The advantage of guided inquiry to empowering the scientific thinking skills is that the teachers are able to guide the students to do some activities by giving an initial question and directing to a discussion (Joyce and Weill, 2010).

Guided inquiry has the advantage of facilities provided by the teachers to empower scientific thinking abilities compared to other inquiry-based learning. According to Banchi and Bell on Janštová, et al (2014) inquiry learning can be divided into four types based on the amount of information and guidance provided by teachers to students. This type starts from the simplest of limited investigation or confirmation, structured inquiry, guided inquiry, to open inquiry. The inquiry begins from (most questions) to open inquiry. Differences in inquiry learning based on student activities in conducting inquiry activities can be seen in Table 1 .

Tabel 1

Comparison of inquiry learning model based on facilities provided by the teacher

\begin{tabular}{lllllll}
\hline & Aspect & & & & & \\
\hline $\begin{array}{l}\text { Level of } \\
\text { inquriy }\end{array}$ & $\begin{array}{l}\text { Problem } \\
\text { Orientation }\end{array}$ & $\begin{array}{l}\text { Problem } \\
\text { formulation }\end{array}$ & Hypothesis & $\begin{array}{l}\text { Research } \\
\text { design }\end{array}$ & $\begin{array}{l}\text { Analysis } \\
\text { Result }\end{array}$ & Conclusions \\
\hline Confirmation & given & given & given & given & $\begin{array}{l}\text { Not } \\
\text { given }\end{array}$ & Not given \\
\hline $\begin{array}{l}\text { Structured } \\
\text { inquiry }\end{array}$ & given & given & given & $\begin{array}{l}\text { Not } \\
\text { given }\end{array}$ & $\begin{array}{l}\text { Not } \\
\text { given }\end{array}$ & Not given \\
\hline $\begin{array}{l}\text { Guided } \\
\text { inquiry }\end{array}$ & given & Not given & Not given & $\begin{array}{l}\text { Not } \\
\text { given }\end{array}$ & $\begin{array}{l}\text { Not } \\
\text { given }\end{array}$ & Not given \\
\hline Open inquiry & Not given & Not given & Not given & $\begin{array}{l}\text { Not } \\
\text { given }\end{array}$ & $\begin{array}{l}\text { Not } \\
\text { given }\end{array}$ & Not given \\
\hline
\end{tabular}

Table 1 shows that guided inquiry learning gives students more opportunities and independence to carry out scientific activities in learning. Guided inquiry does not 
provide the formulation of problems and hypotheses to be investigated, but students independently determine their own up to the design of the experiments to be conducted. This Inquiry is different from confirmation and structured inquiry where students are given problems and hypotheses that have been made by the teacher to be investigated. The opportunities given by students to be more involved in scientific activities are expected to be able to optimise students' scientific thinking abilities.

The successful of implementation of guided inquiry learning to empower students' scientific abilities is also influenced by the types of scientific activities. According to Asmoro, et al (2018) the scientifict activity is a stages of activities based on scientific methods to solve a problem. The correct scientific activity is the accuracy of students doing the steps in implementing scientific methods in order to solve a problem. According to Suciati, et al (2018) stages of an appropriate and systematic scientific method are observational activities, awareness of scale, logical inference in constructing hypotheses, causal laws, logical frames, logical consistency, modelling, and abstraction. According to Wenning (2010) The correct steps of scientific method are formulating the Problem, Formulating Hypothesis, Planning an Experiment, Conducting an Experiment, Communicating.

In the other hand, the fact occurs in the field that there are many students who do the wrong scientific activities. Based on the analysis of researchers about the types of scientific activities that students have used instruments such as student worksheets, It is found that there are three types of students' scientific activities. They are presented in Table 2 .

Table 2

The type of student's scientific activity based on step accuracy

\begin{tabular}{llllllll}
\hline Type & Step 1 & Step 2 & Step 3 & Step 4 & Step 5 & Step 6 & Conclusion \\
\hline \multirow{2}{*}{ a } & \multirow{2}{*}{ Observing } & $\begin{array}{l}\text { Formulating } \\
\text { the Problem }\end{array}$ & $\begin{array}{l}\text { Formulating } \\
\text { Hypothesis }\end{array}$ & $\begin{array}{l}\text { Planning an } \\
\text { Experiment }\end{array}$ & $\begin{array}{l}\text { Conducting an } \\
\text { Experiment }\end{array}$ & $\begin{array}{l}\text { Communicating } \\
\text { accurate }\end{array}$ \\
\hline \multirow{2}{*}{ b } & Observing & $\begin{array}{l}\text { Formulating } \\
\text { the Problem }\end{array}$ & $\begin{array}{l}\text { Planning an } \\
\text { Experiment }\end{array}$ & $\begin{array}{l}\text { Conducting an } \\
\text { Experiment }\end{array}$ & $\begin{array}{l}\text { Formulating } \\
\text { Hypothesis }\end{array}$ & Communicating & $\begin{array}{l}\text { Less } \\
\text { accurate }\end{array}$ \\
\hline \multirow{2}{*}{$\mathrm{c}$} & $\begin{array}{l}\text { Formulating } \\
\text { Problem }\end{array}$ & Observing & $\begin{array}{l}\text { Planning an } \\
\text { Experiment }\end{array}$ & $\begin{array}{l}\text { Conducting an } \\
\text { Experiment }\end{array}$ & $\begin{array}{l}\text { Formulating } \\
\text { Hypothesis }\end{array}$ & Communicating & inaccurate \\
\hline
\end{tabular}

Swarat, S., et al (2012) in their research found that there is a linear correlation between the type of scientific activities and the students' concept mastery. The study finds that the students who do the correct types of scientific activities have a high mastery of the science concepts. In other words, the types of scientific activities that students have are also related to their scientific thinking skills.

The implementation of guided inquiry-based learning is expected to be the solution to empower students' scientific thinking abilities and various types of students' scientific activities. The implementation of guided inquiry-based learning is expected to make teachers as facilitators to help students to describe something abstract by using picture, photograph, chart, scheme and others. Likewise, the complex concept can also be explained in a simple way which is suited to the types of students' scientific activities. Therefore, the empowerment of scientific thinking abilities are more optimal. 
Empowerment of scientific thinking skills is contained at each stage of guided inquiry learning. In the stage of formulating problems and hypotheses, students will be trained independently to convey their arguments. Guided inquiry stages that provide more opportunities for students to work scientifically cause the guided inquiry model is more optimal in strengthening students' scientific thinking abilities than the level of inquiry below that is structured inquiry. In structured inquiry models, the teacher's role is still more dominant in providing problems, composing problem formulations, making hypotheses to planning experiments. The dominance of the teacher's role causes students to think scientifically less optimally trained. Training in scientific thinking skills in structured inquiry models only occurs at the stage where students conduct investigations and make conclusions. On the other hand, the model that is often applied in schools is the expository model. The weakness of expository models in increasing the ability to think scientifically that is the stages in it are not related to all aspects of scientific thinking abilities. Stages of expository models that are more centered on the teacher explain the learning material then ask students not to train students to self-establish, analyze, and make conclusions (Putra, et al, 2018). Therefore, to test the effectiveness of guided inquiry on the students' scientific thinking skills need to be compared with structured inquiry and expository models.

Based on the background of the problem, the researchers find it necessary to conduct a research which aims at investigating: (1) effect of guided inquiry learning model on scientific thinking skills compared to both structured and expository learning; (2) effect of different types of scientific activities on scientific thinking skills; (3) interaction between learning models and types of scientific activities on scientific thinking skills.

\section{METHOD}

\section{Research Design}

This research used the quasi-experimental research. It employed non-equivalent pre-test and post-test control group design. It involved three classes, namely: Experimental Class 1 (the learning uses guided inquiry learning device), Experimental Class 2 (the learning uses structured inquiry learning device), and Experimental Class 3 (the learning uses expository learning device). This study used the $3 \times 3$ factorial design.

\section{Participants}

The population of this research was 1.768 eleventh grade science students (hereinafter called XI MIPA) of 8 SMANs in Pacitan regency. Purposive sampling technique was used to determine its samples. The samples were chosen by considering the quality of schools seen from the national examination score in 2018. There were three selected schools with high, moderate, and low quality. Such a consideration was intended to represent the population.

Each sample school was randomly chosen. There were three classes. The first class was Experimental Class 3 using expository learning lesson learning device as control. The second and third classes were Experimental Class 2 applying the structured inquiry learning device, and Experimental Class 1 using the guided inquiry learning device. The 
samples were 88 students from high quality schools, 89 students from medium quality schools, and 86 student from low quality ones.

Each class group was then divided into groups of students with Scientific Activity Type a, students with Scientific Activity Type b, and students with Scientific Activity Type c. They were divided into those groups through test. The test was in the form of student worksheet that had to be completed using scientific activities coherently. The researcher mapped out the type of scientific activity from the systematic analysis of students' steps in completing the worksheet.

In Experimental Class 1, the number of students with Scientific Activity Type a was 26, that of students with Scientific Activity Type b was 28, and that of students with Scientific Activity Type c was 34. In Experimental Class 2, the number of students with Scientific Activity Type was 25 , that of students with Scientific Activity Type was 28 , and that of students with Scientific Activity Type c was 37. In Experimental Class 3, the number of students with Scientific Activity Type a was 22, that of students with Scientific Activity Type was 26, and that of students in Scientific Activity Type c was 27.

Based on that category, to equalise the amount of the analysed data from each group sample, each sample class consisted of only 22 students. All students in the class were exposed to the same treatment though the analysed data were only from 22 students from each sample group. The distribution of research samples is presented in Table 3 .

Table 3

Distribution of the samples.

\begin{tabular}{llllll}
$\begin{array}{l}\text { Type of Scientific } \\
\text { Activity }\end{array}$ & Experiment & $\begin{array}{l}\text { SMAN 1 } \\
\text { Pacitan }\end{array}$ & $\begin{array}{l}\text { SMAN 1 } \\
\text { Ngadirojo }\end{array}$ & $\begin{array}{l}\text { SMAN } \\
\text { Tulakan }\end{array}$ & EStudents \\
\hline \multirow{3}{*}{ a } & Guided Inquiry $\left(\mathrm{X}_{1}\right)$ & 9 & 9 & 8 & 26 \\
\cline { 2 - 6 } & Structured Inquiry $\left(\mathrm{X}_{2}\right)$ & 9 & 8 & 8 & 25 \\
\cline { 2 - 6 } & Expository $\left(\mathrm{X}_{3}\right)$ & 8 & 7 & 7 & 22 \\
\hline \multirow{3}{*}{$\mathrm{b}$} & Guided Inquiry $\left(\mathrm{X}_{1}\right)$ & 12 & 8 & 8 & 28 \\
\cline { 2 - 6 } & Structured Inquiry $\left(\mathrm{X}_{2}\right)$ & 7 & 10 & 11 & 28 \\
\cline { 2 - 6 } $\mathrm{c}$ & Expository $\left(\mathrm{X}_{3}\right)$ & 11 & 13 & 12 & 36 \\
\hline \multirow{2}{*}{ Total } & Guided Inquiry $\left(\mathrm{X}_{1}\right)$ & 9 & 13 & 12 & 34 \\
\cline { 2 - 6 } & Structured Inquiry $\left(\mathrm{X}_{2}\right)$ & 14 & 12 & 11 & 37 \\
\cline { 2 - 6 } & Expository $\left(\mathrm{X}_{3}\right)$ & 9 & 9 & 9 & 27 \\
\hline
\end{tabular}

\section{Instrumentation and Data Collection Technique}

The experimental class learning instrument used the Structured Inquiry and Inquiry Lesson Plan prepared by researchers and equipped with student worksheets, while the expository lesson plan was the lesson plan commonly used by SMA Negeri in Pacitan as the research population. Learning was carried out for 2 meetings on the material of the reproductive system, and then concluded with a post-test.

The instrument of post-test data collection used an essay test prepared based on the rubric of Kuhn's scientific thinking skills (2010), which is integrated with the reproductive system material competence. According to Kuhn (2010) the indicators of 
scientific thinking skills include by inquiry, analysis, inference and argument. Each indicator was organized into an essay test questions that students had work on within 60 minutes. In each question work, students were expected to be able to use the scientific thinking process optimally. For example in the analysis aspect, students were expected to be able to analyse the impact of abortion on the health of the reproductive system.

The other test was the student's scientific activity test. The test type was like a worksheet which serves to measure the systematic of scientific activity in finishing the test. Students were asked to observe the phenomena, formulate a problem, write a hypothesis, design an experiment, and make conclusions. The results of the mapping of scientific activity patterns were based on the accuracy of the students and the student's complicity in completing the test. Furthermore, the results of the mapping of scientific activity patterns were grouped into three scientific activity patterns; Type a was accurate, Type b was less accurate, and Type $\mathrm{C}$ is inaccurate. Before using the instrument, it was also validated by the expert validators. They were science education lecturers and science experts. Validation by science education experts obtained a value of 47 points from a maximum score of 56 points validation, thus the percentage of validation scores reached $83.93 \%$ and was declared very feasible. Then, validation by a science expert gets 148 points out of 165 points with a maximum score, thus the percentage of eligibility by science experts reaches $89.69 \%$ so it is worth using.

\section{Data Analysis Technique}

The techniques used to test the hypothesis were both descriptive statistical analysis and inferential statistical analysis. Descriptive statistical analysis used included mean, difference, and standard deviation. Meanwhile, the inferential statistical analysis used to test hypotheses was the analysis of covariance (ANCOVA) with the significance level of $5 \%$. The pre-test score was the covariate.

The prerequisite test of the pre-test and post-test score had firstly been conducted before ANCOVA test was conducted. The prerequisite tests used in this study were the normality and homogeneity tests by using Kolmogorov-Smirnov's test and Levene's test. The difference in the average value of scientific thinking abilities was then tested using the LSD advanced test. The statistical calculation was calculated by using SPSS Version 16.0 program with the significance level of 0.05 .

\section{FINDINGS}

\section{Pre-requisite Test Analysis}

\section{Normality and Homogeneity Test}

The data tested for normality in this study were those of pre-test and post-test. The researchers used Kolmogorov-Smirnov's test with $\alpha=0.050$. The value of the sample class was greater than Sig. value 0.05 ( $\mathrm{Sig}>0.05$ ). Therefore, the sample from the population could be stated normally distributed. The pre-test and post-test data in this study were also tested using Levene's test with $\alpha=0.050$ to decide whether the data were homogenous or not. The result of the test shows that the Sig. values was 0.60 (> $0.05)$. Therefore, the student's scientific thinking abilities data had the same variance or 
were homogeneous. The result of the prerequisite test shows that the data in this study were eligible for hypothetical test using ANCOVA statistical parametric.

\section{Hypothesis Testing}

The data of scientific thinking abilities in this study were tested by using ANCOVA with the help of computer program--SPSS 17. The result of ANCOVA test of scientific thinking abilities on the source of learning device, the type of scientific activity, and the interaction between the implementation of learning devices with the type of scientific activity of students is presented in Table 4 .

Table 4

ANCOVA test result of the students' scientific thinking abilities

\begin{tabular}{llllll}
\hline Source & JK & Db & RK & F & Sig. \\
\hline Corrected Model & $6418.803 \mathrm{a}$ & 9 & 713.200 & 5.367 & .000 \\
\hline Intercept & 59321.556 & 1 & 59321.556 & 446.447 & .000 \\
\hline PP & 59.167 & 1 & 59.167 & .445 & .505 \\
\hline Type of Activity & 1361.446 & 2 & 680.723 & 5.123 & .007 \\
\hline Pre-test & 2097.671 & 2 & 1048.835 & 7.893 & .001 \\
\hline Type of Activity*PP & 2485.770 & 4 & 621.443 & 4.677 & .001 \\
\hline Error & 24980.470 & 188 & 132.875 & & \\
\hline Total & 913000.000 & 198 & & & \\
\hline Corrected Total & 31399.273 & 197 & & & \\
\hline a. R Squared = .811 (Adjusted R Squared $=.609)$ & & & \\
\hline
\end{tabular}

The table shows that the corrected model obtained score was sig. $=0,000(<\alpha=0.050)$, therefore $\mathrm{H}_{0}$ was not verified, meaning that there was a significant influence of the implementation of learning device on the scientific thinking abilities. From these result, the LSD test could be conducted to determine the level of influence of each learning device on students' scientific thinking abilities. The LSD test data can be seen in Table 5.

Table 5

LSD test result of learning device on scientific thinking abilities

\begin{tabular}{llllll}
\hline Device & Pre-test Average & Post-test Average & Difference & Corrected Average & Notation \\
\hline Expository & 50.00 & 63.27 & 13.27 & 62.00 & $\mathrm{~A}$ \\
\hline Structured inquiry & 42.79 & 65.21 & 22.42 & 63.90 & $\mathrm{~A}$ \\
\hline Guided inquiry & 39.45 & 71.10 & 32.24 & 70.85 & $\mathrm{~B}$ \\
\hline
\end{tabular}

Table 5 shows that the LSD test result of the three learning models had different notations. This result indicates that there was a significant difference between the implementation of guided inquiry learning model and those of structured and expository inquiry models. On the other hand, the structured inquiry and expository learning models did not have a significant difference on increasing student's scientific thinking abilities. The average score of corrected scientific thinking abilities indicates that the implementation of guided inquiry learning model had the highest potential in increasing scientific thinking abilities that is equal to 70.85, meanwhile that of structured inquiry learning models had a higher potential compared to the expository learning model, 63.90 compared to 62.00 . 
Table 5 also shows that there was an increased score of the students' thinking abilities seen from the difference between the pre-test score and post test score. The increases (in percentage) of the students' scientific thinking abilities after the implementations of guided inquiry-based learning model, structured inquiry-based learning model, and expository learning model were $46 \%$, and $35 \%$ only $21 \%$ respectively. The data show that the implementation of guided inquiry-based learning model had the highest potential in empowering scientific thinking abilities. Based on the data of the ANCOVA test result in Table 5, the obtained value on the source of type of scientific activity was sig. $=0.007(<0.05)$, then $\mathrm{H}_{1}$, which states that there was difference of influence between the type of students 'scientific activity on students' scientific thinking abilities, was accepted. Therefore, the LSD test could be conducted to investigate the level of variation influence of the type of student's scientific activity on students' scientific thinking abilities. The LSD test result of the effects of type of scientific activity on students' scientific thinking abilities is presented in Table 6.

Table 6

LSD test result of scientific thinking abilities from type of scientific activity data source

\begin{tabular}{llllll}
\hline $\begin{array}{l}\text { Type of Scientific } \\
\text { Activity }\end{array}$ & $\begin{array}{l}\text { Pre-test } \\
\text { Average Score }\end{array}$ & $\begin{array}{l}\text { Post-test } \\
\text { Average Score }\end{array}$ & Difference & $\begin{array}{l}\text { Average } \\
\text { Corrected Score }\end{array}$ & Notation \\
\hline $\mathrm{b}$ & 43.27 & 64.00 & 21.30 & 63.73 & $\mathrm{~A}$ \\
\hline $\mathrm{c}$ & 44.42 & 66.72 & 20.79 & 63.99 & $\mathrm{~A}$ \\
\hline $\mathrm{a}$ & 44.55 & 70.39 & 25.84 & 68.82 & $\mathrm{~B}$ \\
\hline
\end{tabular}

The table shows that students with Scientific Activity Type a was clearly different from those with Scientific Activity Type b, while the students with Scientific Activity Type c was not significantly different from those with Scientific Activity Types a and b. The students with Scientific Activity Type a had average corrected score on scientific thinking abilities of 68.82. It was greater than both students with Scientific Activity Type c and those with Scientific Activity Type b. The students with Scientific Activity Type c had average corrected score of 63.99. It was greater as much as 0.16 than that of the students with Scientific Activity Type b. These results indicate that the Scientific Activity Type a had the most significant effect compared to Scientific Activity Types b and $\mathrm{c}$.

The shift percentage of pre-test average score to post-test average score of the students with Scientific Activity Type a was $38 \%$ while the students with Scientific Activity Type b was $33 \%$ and the students with Scientific Activity Type c was $32 \%$. These results indicate that the students with Scientific Activity Type a had a higher scientific thinking abilities than both the students with Scientific Activity Type b and those Scientific Activity Type c. Meanwhile, the increased score of the students with Scientific Activity Type b was higher than that of the students with Scientific Activity Type c, even though its corrected average score was greater.

ANCOVA test result in Table 4 shows that the significance value on interaction data source between the type of scientific activity and learning model was $0.001(<0.05)$, therefore $\mathrm{H}_{0}$ was not verified rejected, indicating that there was an interaction influence between implementation of learning model and the type of scientific activity on 
scientific thinking abilities. The position of each interaction between the implementation of learning model and the type of scientific activity was further tested using the LSD test with the significance value of 0.05 as presented in Table 7.

Table 7

LSD test result between learning models and type of scientific activity on scientific thinking abilities

\begin{tabular}{lllllll}
\hline Learning Model & $\begin{array}{l}\text { Type of Scientific } \\
\text { Activity }\end{array}$ & $\begin{array}{l}\text { Pre- } \\
\text { test }\end{array}$ & $\begin{array}{l}\text { Post- } \\
\text { test }\end{array}$ & Difference & $\begin{array}{l}\text { Average } \\
\text { Corrected }\end{array}$ & Notation \\
\hline Expository & $\mathrm{a}$ & 47.27 & 60.82 & 13.55 & 59.20 & $\mathrm{a}$ \\
\hline Structured inquiry & $\mathrm{b}$ & 40.91 & 60.91 & 20.00 & 59.90 & $\mathrm{a} \mathrm{b}$ \\
\hline Structured inquiry & $\mathrm{c}$ & 43.64 & 61.18 & 17.54 & 60.18 & $\mathrm{a} \mathrm{b}$ \\
\hline Expository & $\mathrm{c}$ & 53.27 & 62.73 & 9.46 & 61.74 & $\mathrm{a} \mathrm{b} \mathrm{c}$ \\
\hline Expository & $\mathrm{b}$ & 49.45 & 66.27 & 16.82 & 65.20 & $\mathrm{a} \mathrm{b} \mathrm{c} \mathrm{d}$ \\
\hline Guided inquiry & $\mathrm{b}$ & 39.45 & 66.55 & 27.1 & 66.29 & $\mathrm{~b} \mathrm{c} \mathrm{d}$ \\
\hline Guided inquiry & $\mathrm{c}$ & 36.36 & 71.73 & 35.37 & 70.55 & $\mathrm{~b} \mathrm{c} \mathrm{d}$ \\
\hline Structured inquiry & $\mathrm{a}$ & 43.82 & 73.55 & 29.73 & 72.39 & $\mathrm{c} \mathrm{d}$ \\
\hline Guided inquiry & $\mathrm{a}$ & 42.55 & 76.82 & 34.27 & 76.06 & $\mathrm{~d}$ \\
\hline
\end{tabular}

Table 7 shows that each interaction occurred between implementation of learning device and type of scientific activity that had varied notations. Guided inquiry learning device which was implemented to group of Scientific Activity Type a students had a similar notation to the interaction between guided inquiry learning device and Scientific Activity Type a students. This fact indicates that inquiry-based learning device which was implemented to Scientific Activity Type a on scientific thinking abilities was not significantly different. The lowest corrected average score was the interaction between Scientific Activity Type a and implementation of expository learning model, but the LSD test notation shows that there was not any significant difference of the interaction between expository learning model implemented in Scientific Activity Type a and Scientific Activity Types $b$ and $c$ in structured inquiry classes. The real difference was shown by the interaction between the implementation of guided inquiry learning device and the students with Scientific Activity Type a and those with Scientific Activity Types $\mathrm{b}$ and $\mathrm{c}$ on the implementation of structured inquiry learning device, and the interaction between all types of scientific activity and the implementation of expository learning model.

The percentage difference between the average post-test and pre-test scores on hypothesis testing showed an increase in student's scientific thinking abilities on Scientific Activity Types a, b, and c in the implementation of guided inquiry learning. It ranged from $4 \% 1$ to $49 \%$. These results indicated a higher increase than the interaction between the type of scientific activity and the implementation of structured and expository inquiry learning. The shift of pre-test and post-test score interaction between the implementation of structured inquiry learning device and the type of scientific activity ranged from $29 \%$ to $40 \%$, while the interaction between expository learning device and type of scientific activity only ranged from $15 \%$ to $25 \%$. 


\section{DISCUSSION}

\section{Effect of Implementation of Learning Model on Scientific Thinking Abilities}

The implementation of Guided inquiry-based learning model in this research has shown a significant effect on improving scientific thinking skills. This is in line with that of Rubiyanto's research (2010) that the students who learn using biology inquiry cards have higher scientific abilities than students who do not. Kristin, Nyeneng, \& Ertikanto (2015) in their research also reveal that guided inquiry-based module can improve students' scientific thinking abilities. Koksal, E. A., and Berberoglu, G. (2014) research state that inquiry instruction can improve students' scientific thinking abilities. Azizmalayeri, Jafari, Sharif, Asgari, \& Omidi (2012) find that the use of guided inquiry to approach a teaching material can significantly influence students' scientific thinking abilities.

Scientific work activities that are structured and systematic with the guidance of the teacher as facilitator become a differentiator of guided inquiry-based learning of other scientific approaches (Wenning, 2010). The guided inquiry model is applied in small groups with teacher who always monitors practicum action. Discussion activities, thinking processes, and assessments of behaviour also occur in inquiry strategies that are applied in small groups. Investigation activities and empowerment of thinking on inquiry-based learning strategies are effectively applied in empowering the abilities to analyse, infer and self-regulation of all group members (Putra B. K. B., Prayitno, B. A., \& Maridi, 2015). This causes the significance of the implementation of inquiry-based learning device more effective than expository and structured inquiry-based learning device on increasing students' scientific thinking abilities.

The result of this study is also in line with previous studies. Anjani, D., Suciati, S., \& Maridi, M. (2017) research finds that inquiry-based learning can improve cognitive thinking abilities and student learning outcome. Students who are able to process more optimal their cognitive thinking skills are believed to have higher scientific thinking abilities than those who are not. This is in line with Fitriyati, I., \& Munzil, M. (2017) opinion that improving cognitive thinking abilities and achieving higher-order thinking skills will positively influence learning outcome and scientific thinking abilities. Fong (2017) conducts a meta-analysis of the relationship between learning outcome and scientific thinking, and he concludes that the abilities to understand concept, which is proven by seeing the learning outcome, is needed to help students to optimise scientific thinking abilities.

This research also shows that the average corrected score of structured inquiry-based learning model is greater than that of expository learning. Inquiry-based learning has a phase that encourages students to work using steps of scientific methods to solve the problems (Gromally et al., 2009; Wenning, 2010). The steps of the scientific method in inquiry have been able to improve students' scientific thinking abilities (Ratnasari, Suciati, \& Maridi, 2018). The steps of the scientific method do not appear in the expository learning model so that students' potential to improve their scientific thinking abilities is lower than those in guided inquiry-based learning and structured inquiry learning. 


\section{The Effect of Type of Scientific Activity on Scientific Thinking Abilities}

The second finding of this study was whether there is a significant effect between the type of scientific activity and student's scientific thinking abilities. Based on the finding in this research, the type of scientific activity influences the scientific thinking abilities, and the highest scientific thinking ability is possessed by students with Scientific Activity Type a. It is precise and systematic. On the other hand, the two other types of scientific activities are less precise. Students in these group have a lower scientific thinking ability. Therefore, scientific activity affects students' scientific thinking abilities. In addition, students who have a higher scientific thinking ability tend to have true type of scientific activities.

The influence of type of scientific activities on scientific thinking abilities occurs because it is the implementation of students' thinking skills through empirical experience using all senses. They use the sense of sight, smell, hearing, taste, and touch in terms of observing, grouping, interpreting, predicting, formulating, formulating hypothesis, communicating product, applying concepts, using tools and materials in conducting experiment and planning the next ones. Similarly, scientific thinking abilities are able to make students focus on their question, analyse the argument, make observation, define the terms, identify assumptions, and make conclusion from all those activities (Magdalena, S.M., 2015).

Ratnasari, et al (2018) mentioned that in answering HOTs (High Order Thinking Skills) questions in a test, students must use or transfer the existing knowledge and skill to answer them or to face difficult situation. Rofiah, et al. (2013) stated that the scientific thinking abilities cannot be possessed directly, but it is obtained through some trainings of the correct and systematic scientific activities. Hertiavi (2010) stated that efforts made by teachers to improve students' scientific thinking abilities are to provide exercises to observe phenomenon, formulate the problem, make hypotheses, design the experiments, express opinions, draw conclusion and discover new concepts for them. The aspect of scientific thinking abilities which is in harmony with the sequence of the scientific activities is also the reason for correlation between the scientific thinking abilities and learning outcomes.

Widyastuti, et al. (2014) stated that scientific thinking is the ability to analyse, criticise, and formulate conclusion based on careful conclusion and consideration. Thus, by doing those activities, they indirectly train the students to complete the concept understanding test of the material. Meanwhile, according to Suciati et al (2018) to become a scientific thinker, it needs complex mental activities. A scientific thinker needs to use not only basic thinking skills but also a variety of psychomotor skill and problem solving procedure. Therefore, the scientific thinking abilities which are continuously trained in the learning process will have an impact on the increase of students' scientific thinking abilities.

At least, the score of students' Scientific Activity Types b and c is less than the students' Scientific Activity Type a. The research of Sigiro's et al (2017) also found that scientific reasoning training affects students' scientific thinking abilities. Training scientific thinking skills can optimally take place if it is supported by good methods, models and 
learning media. Product development of learning device which focuses on training the scientific thinking skills is one of the solutions to change Biology learning so that the students are able to be scientific thinkers and their learning outcome get better.

\section{The Interaction between the Implementation of Learning Devices and the Type of Scientific Activity on Students' Scientific Thinking Abilities}

The result hypothesis test using ANCOVA shows there is an interaction between the guided inquiry-based learning device and the type of scientific activity on the scientific thinking abilities. The implementation of both guided inquiry-based learning and type of students' scientific activity contribute to scientific thinking abilities. In other words, the effect combination between the two becomes visible.

Meanwhile, in the process of inquiry or discovery, it needs courage, confidence and a high optimism attitude. They are needed to solve the problem by establishing the allegation and designing an experiment to test the allegation. Students who have correct and systematic type of scientific activity do this more easily. The courage of students to ask when encountering difficulties in the inquiry process indicates the occurrence of the scientific process in learning through the inquiry approach.

These findings are in accordance with the research finding of Prayitno et al (2017), which says that inquiry-based learning is effective to improve higher order thinking skills. One of them is the scientific thinking ability. The effectiveness of guided inquirybased model in increasing students' scientific thinking abilities of Types a, b, and c on the concept of reproductive system material is done through optimising scientific work path. The steps of the scientific method in this study are applied in the learning of reproductive material such as observing the reproductive system organs and menstrual cycle calculations. Therefore, students who have Scientific Activity Types b and c find it difficult to follow the guided inquiry-based learning, which has an impact on their scientific thinking abilities. In addition, the remaining students from Scientific Thinking Activity Types $b$ and $c$ are treated with the implementation of guided inquiry-based learning devices are also less optimal.

The LSD test notation shows that students who have Scientific Activity Type a with inquiry-based approach have higher scientific thinking abilities compared to those with Scientific Activity Types b and c. This result indicate that students who have the right type of scientific activity combined with the inquiry learning approach can be more adaptive so that their grades are higher than the students with Scientific Activity Types b and c. These results are supported by the opinion of Khuhlthau, et al (2015) which states that inquiry is a scientific method formulated into a learning strategy so that students who have the ability to carry out the correct scientific method are of course more able to follow inquiry learning strategies than those who have never done a scientific method.

Table 7 shows how learning strategies interact with patterns of student activity towards scientific thinking abilities. LSD test shows that the interaction of inquiry-based models both guided inquiry and structured inquiry is less effective in applying it to students with the wrong scientific activity patterns namely types b and c.The students with Scientific Activity Types $b$ and $c$ found difficulty when the researchers explained some steps of inquiry learning. They found it difficult to observe the phenomenon, formulate the 
problem, formulate hypotheses, design an experiment, and analyse the data to make conclusion. Both approaches are rarely implemented to them, and the process of integration with students is limited in time. The findings of this research is in line with the research of Suciati \& Prayitno (2018), which stated the application of inquiry-based learning becomes less optimal when applied to classes with different learning abilities, and therefore there is a need for collaborative strategies to support inquiry learning that can optimize the scientific thinking ability of all students in the class.

On the other hand, Scientific Activity Type a on expository learning model shows that the value of scientific thinking abilities is less optimal. This result exists because expository learning does not fully accommodate the scientific thinking skill training. It can also be seen in the students of Scientific Activity Types b and $c$ where the result of scientific thinking abilities is less optimal. This finding is in line with the statement of Orgad (2014) that scientific thinkers can be prepared optimally through trainings which actively involve students in conducting experimental activities, analysing data, and providing solutions to problems rather than question-and-answer learning process.

In the implementation of guided inquiry-based learning, students are directly involved in shaping material concept through stages of learning that are identical to the scientific method. The scientific method itself includes systematic types of scientific activity that students must do. All of these learning activities have been summarized in guided inquiry learning model through the development of process skill. This is in line with opinion of Brown, P.J. (2010) which states that the techniques needed in learning Biology are the same as those in scientific inquiry. The scientific method can be considered as an inquiry process. One of the advantages of learning with the guided inquiry model is the possibility of students to solve open-ended problem and have alternative solution to solve the problem in more than one way, because it depends on how they construct their own answer but still with the guidance from the teachers as facilitators. In addition, it is possible for them to find ways and solutions that are new or have never been found by others. Thus, this allows a deeper understanding of the concept after discussing with their friends or with their teachers.

\section{CONCLUSIONS}

The implementation of inquiry-based learning had a significant effect on scientific thinking abilities of XI IPA students of SMAN in Pacitan. The type of students' scientific activities significantly affects the scientific thinking abilities of XI IPA students of SMAN in Pacitan. Scientific Activity Type a or the right type of scientific activity trained the students to have higher scientific thinking abilities than the inappropriate type of scientific activity patterns (Types b and c). There was an interaction between the implementation of guided inquiry-based learning device and the type of student' scientific activity on scientific thinking abilities of the XI MIPA students of SMAN in Pacitan. This researchs result suggests the right pattern of scientific activity begins with students observing, formulating problems, making hypotheses, collecting and analyzing data, then making conclusions, if students are able to carry out scientific activities appropriately, then the scientific thinking skills can be empowered optimally using guided inquiry learning. The results of this study can be used as a basis for testing 
the effectiveness of guided inquiry-based learning set on other variables, such as critical thinking skills, cognitive abilities, social skills, and others.

\section{REFERENCES}

Asmoro, S. P., Suciati., \& Prayitno, B. A. (2018). A Profile Analysis of Scientific Thinking Ability ofX I Grade Senior High School Students in PacitanRegency. Advances in Social Science, Education and Humanities Research (ASSEHR), 267, 188-192.

Coffman, T. (2017). Inquiry-Based Learning: Designing Instruction to Promote Higher Level Thinking. Rowman \& Littlefield.Chicago.

Farida, I. A., Suminar, D. R. \& Nawangsari, N. A. F. (2017). Developing Scientific Thinking Through Inquiry Learning. Advances in Social Science, Education and Humanities Research, 164, 11-16.

Galton, M., Hargreaves, L. \& Pell, T. (2009). Group Work and Whole-Class Teaching with 11- to 14-Year-Olds Compared. Cambridge Journal of Education, 39(1), 119-140.

Gerde, H. K., Schachter, R. E., \& Wasik, B. A. (2013). Using the scientific method to guide learning: An integrated approach to early childhood curriculum. Early Childhood Education Journal, 41(5), 315-323.

Hendrich, Suzanne., Licklider,Barbara., Thompson, Katherine., Haynes, Cynthia. \&Wiersema, Jan. (2018). Development of Scientific Thinking Facilitated by Reflective Self-Assessment in a Communication-Intensive Food Science and Human Nutrition Course. Journal of Food Science Education, 17(1), 8-13.

Hoover, K. R., \& Donovan, T. (2010). The elements of social scientific thinking. Cengage Learning.

Janštová, V., Pavlasová, L., \& Černý, J. (2014). Inquiry based laboratory exercise focused on proteins. Projektové vyučování v přirodovědných předmètech XI., Praha, 48-55.

Jewett, Elizabeth., \&Kuhn, Deanna. (2015). Brief Report: Social science as a tool in developing scientificthinking skills in underserved, low-achievingurban students. Journal of Experimental Child Psychology. 1-8.

Kagee, Ashraf., Allie, Saalih., \& Lesch, Anthea. (2010). Effect of a course in research methods onscientific thinking among psychology students. South African Journal of Psychology, 40, (3), 272-281.

Khan, R. M. A., Nadeem, I. \& Saina, T. (2016). The Influence of Parents Educational Level on Secondary School Students Academic Achievements in District Rajanpur. Journal of Education and Practice, 6(6), 76-79.

Koerber, Susanne., Mayer, Daniela., Osterhaus, Christopher. \& Schwippert, Knut. (2015). The Development of Scientific Thinking in Elementary School: A Comprehensive Inventory. Journal of Child Development, 86, (1), 327-336.

Koksal, E. A., \& Berberoglu, G. (2014). The effect of guided-inquiry instruction on 6th grade Turkish students' achievement, science process skills, and attitudes toward science. International Journal of Science Education, 36(1), 66-78. 
Kuhlthau, C. C., Maniotes, L. K., \& Caspari, A. K. (2015). Guided inquiry: Learning in the 21st century: Learning in the 21st century. Abc-Clio.

Kuhn, Deanna. (2010). What is Scientific Thinking and How Does it Develop? Handbook of Childhood Cognitive Development. 2nd ed. New York: Columbia University.

Lackaff, Julie dan Hoisington, Cynthia. (2013). Scientific Thinking Background and Criteria. Scientific Thinking Research Summary for The Work Sampling System. 5th ed. USA: Pearson Education, Inc.

Milkova, Stiliana. (2012). Strategies for effective lesson planning. Center for Research on learning and Teaching: 1-4.

Morris, B. J., Croker, S., Masnick, A. M., \& Zimmerman, C. (2012). The emergence of scientific reasoning. In H. Kloos, B. J. Morris, \& J. L. Amaral (Eds.), Current topics in children's learning and cognition (pp. 61-82). Rijeka,Croatia: InTech.

Ngang, T.K., Subadrah, N. \& Bouphan, P. (2013). Developing Instruments to Measuring Thinking Skills and Problem Solving skills Among Malaysian School Pupils. Procedia Social and Behavioral Science, 116, 3760-3764.

Prayitno, B. A., \& Suciati, S. (2018). Enhancing Students' Higher Order Thinking Skills In Science Through Instad Strategy. Journal of Baltic Science Education, 17(6), 1046.

Putra, B. K. B., B. A. Prayitno, and M. Maridi. (2018). The Effectiveness of Guided Inquiry and INSTAD towards Students' Critical Thinking Skills on Circulatory System Materials. Jurnal Pendidikan IPA Indonesia, 7(4), 476-482.

Ratnasari, D., Suciati, S., \& Maridi, M. (2019). Empowering scientific thinking skills through creative problem solving with scaffolding learning. JPBI (Jurnal Pendidikan Biologi Indonesia), 5(1), 61-68.

Saavedra, A. R., \& Opfer, V. D. (2012). Learning 21st-century skills requires 21stcentury teaching. Phi Delta Kappan, 94(2), 8-13.

Suciati, S., Ali, M. N., Anggraini, A. F., \& Dermawan, Z. (2018). The Profile of XI Grade Students' Scientific Thinking Abilities on Scientific Approach Implementation. Jurnal Pendidikan IPA Indonesia, 7(3), 341-346.

Sudarisman, Suciati. (2015). Memahami Hakikat dan Karakteristik PembelajaranBiologi Dalam Upaya Menjawab Tantangan Abad 21 Serta Optimalisasi Implementasi Kurikulum 2013. Jurnal Florea Volume, 2(1), 29-35.

Swarat, S., Ortony, A., \& Revelle, W. (2012). Activity matters: Understanding student interest in school science. Journal of research in science teaching, 49(4), 515-537.

Thitima, Gamlunglert. \& Sumalee, Chaijaroen. (2012). Scientific Thinking of The Learners Learning with The Knowledge Construction Model Enhancing Scientific Thinking. ProcediaSocial and Behavioral Sciences, 46, 3771-3775.

Trowbridge, Leslie W. andBybee, Rodger W. (1996). Teaching Secondary School Science-Strategies for Developing Scientific Literacy. New Jersey: Prentice Hall, 1996.

Wenning, C.J. (2010). Assessing Inquiry Skills as a Component of Scientific Literacy. Journal of Physics Teacher Education Online, 4(2), 21-24. 